\title{
Biofilm Formation, Epiphytic Fitness, and Canker Development in Xanthomonas axonopodis pv. citri
}

\author{
Luciano A. Rigano, ${ }^{1}$ Florencia Siciliano, ${ }^{2}$ Ramón Enrique, ${ }^{2}$ Lorena Sendín, ${ }^{3}$ Paula Filippone,${ }^{3}$ \\ Pablo S. Torres, ${ }^{1}$ Julia Qüesta, ${ }^{2}$ J. Maxwell Dow, ${ }^{4}$ Atilio P. Castagnaro, ${ }^{3}$ Adrián A. Vojnov, ${ }^{1}$ and \\ María Rosa Marano²
}

${ }^{1}$ Fundación Pablo Cassará, Centro de Ciencia y Tecnología "Dr. Cesar Milstein," Saladillo 2468 C1440FFX, Ciudad de Buenos Aires, Argentina; ${ }^{2}$ Instituto de Biología Molecular y Celular de Rosario-CONICET, División Virología, Departamento Microbiología, Facultad de Ciencias Bioquímicas y Farmacéuticas, UNR. Suipacha 531, 2000. Rosario, Argentina; ${ }^{3}$ Estación Experimental Agroindustrial Obispo Colombres, Casilla No. 9, Las Talitas, 4101, Tucumán, Argentina; ${ }^{4}$ BIOMERIT Research Centre, Department of Microbiology, National University of Ireland, Cork, Ireland

Submitted 13 April 2007. Accepted 5 June 2007.

\begin{abstract}
The phytopathogenic bacterium Xanthomonas axonopodis pv. citri is responsible for the canker disease affecting citrus plants throughout the world. Here, we have evaluated the role of bacterial attachment and biofilm formation in leaf colonization during canker development on lemon leaves. Crystal violet staining and confocal laser scanning microscopy analysis of $X$. axonopodis pv. citri strains expressing the green fluorescent protein were used to evaluate attachment and biofilm formation on abiotic and biotic (leaf) surfaces. Wild-type $X$. axonopodis pv. citri attached to and formed a complex, structured biofilm on glass in minimal medium containing glucose. Similar attachment and structured biofilm formation also were seen on lemon leaves. An $X$. axonopodis pv. citri gumB mutant strain, defective in production of the extracellular polysaccharide xanthan, did not form a structured biofilm on either abiotic or biotic surfaces. In addition, the $X$. axonopodis pv. citri gumB showed reduced growth and survival on leaf surfaces and reduced disease symptoms. These findings suggest an important role for formation of biofilms in the epiphytic survival of $X$. axonopodis pv. citri prior to development of canker disease.
\end{abstract}

Additional keywords: Citrus limon, EPS, GFP-labeled X. axonopodis pv. citri.

In natural ecosystems, microorganisms grow preferentially attached to surfaces, forming matrix-enclosed biofilms (Kolter and Greenberg 2006; Parsek and Fuqua 2004; Ramey et al. 2004; Stoodley et al. 2002). Microbial biofilms generally are defined as conglomerates of cells immobilized in an organic polymer matrix of microbial origin, with extracellular polysaccharides (EPSs) as the major constituent, along with proteins, lipids, and nucleic acids (Branda et al. 2005; Southey-Pillig et al. 2005; Steinberger and Holden 2005; Sutherland 2001).

Bacteria in biofilm have a different physiology from that of free-living (planktonic) cells. They generally live under nutrient limitation, which may promote the exchange of genetic

\section{A. Rigano and F. Siciliano contributed equally to this work.}

Corresponding authors: M. R. Marano; E-mail: marano@ibr.gov.ar and A. Vojnov; E-mail: avojnov@ fundacioncassara.org.ar material and generate more diversity than planktonic populations (Boles et al. 2004). Biofilms also are known to protect bacteria from environmental stresses, host defense mechanisms, and antimicrobial compounds (Branda et al. 2005; Camilli and Bassler 2006; Leid et al. 2005; Parsek and Fuqua 2004).

An association between biofilm formation and virulence has been reported for a variety of chronic bacterial infections in humans (Costerton et al. 1999; Parsek and Singh 2003). However, few studies have examined the role of biofilm formation in the development of bacterial diseases in plants (Crossman and Dow 2004; Kang et al. 1999; Koutsoudis et al. 2006; Osiro et al. 2004; Ramey et al. 2004). The ability to produce EPS is critical for biofilm formation in a number of pathogenic bacteria. Attachment and survival of bacteria on host tissue requires biofilm formation; as such, it is not surprising that EPS production is correlated with virulence in numerous bacteria (Dow et al. 2003; Fujishige et al. 2006; Laue et al. 2006).

Xanthan, the EPS produced by xanthomonads, is a polymer of repeating pentasaccharide units with the mannose- $(\beta-1,4)$ glucuronic acid- $(\beta-1,2)$-mannose- $(\alpha-1,3)$-cellobiose structure (Jansson et al. 1975). Production of xanthan is regulated in part by a cell-to-cell signaling system encoded by a cluster of regulation of pathogenicity factors $(r p f)$ genes and the diffusible signal factor (DSF) (Crossman and Dow 2004; Dow et al. 2003). In Xanthomonas campestris pv. campestris, the biosynthesis of xanthan gum is directed by a cluster of 12 genes ( $g u m B$ to $-M$ ); the function of most of the protein products has now been assigned (Katzen et al. 1998; Vojnov et al. 1998, 2002 ). Functional gumB and gumC genes are necessary for the production of mature extracellular xanthan from pentasaccharide intermediates (Vojnov et al. 1998).

$X$. axonopodis pv. citri is the bacterial pathogen responsible for citrus canker - the citrus disease with greatest worldwide impact. X. axonopodis pv. citri invasion of host mesophyll is accomplished through natural openings, such as stomata, and through lesions (Brunings and Gabriel 2003). Canker symptoms on leaves and fruit are characterized by surface-penetrating necrotic lesions surrounded by oily, water-soaked margins and yellow chlorotic rings (Brunings and Gabriel 2003). The canker itself, along with surviving populations of bacteria, constitutes the principal sources of disease spread (Cubero and Graham 2004).

Most phytopathogenic bacteria exist as epiphytes on healthy plants prior to colonization, and the probability of disease occur- 
rence is related directly to the epiphytic population size of the pathogen (Hirano and Upper 1983). In this study, we have investigated biofilm formation by $X$. axonopodis pv. citri and the possible role of biofilm in epiphytic fitness and canker development. We show that $X$. axonopodis pv. citri forms structured biofilms both in vitro on glass slides and in vivo on citrus leaves. In contrast, an $X$. axonopodis pv. citri gum mutant strain defective in xanthan synthesis was unable to form a structured biofilm either in vitro or in vivo and was compromised for epiphytic survival and disease development in plants. These findings point to the importance of biofilm formation in the epiphytic phase of canker disease.

\section{RESULTS}

\section{Isolation of xanthan-deficient mutant in $X$. axonopodis pv. citri.}

The work in this article investigates biofilm formation in $X$. axonopodis pv. citri and the role of xanthan in the various steps leading to a mature biofilm. In order to investigate the role of xanthan in biofilm formation, it was necessary to create a mutant strain of $X$. axonopodis pv. citri specifically deficient in the production of the polysaccharide. Genome comparison of $X$. axonopodis pv. citri (strain 306) (da Silva et al. 2002) and $X$. campestris pv. campestris (strain 8004) (Qian et al. 2005) revealed that the gum gene cluster, involved in $X$. campestris pv. campestris xanthan biosynthesis, is largely conserved in both bacteria in terms of size and gene order, indicating that $X$. axonopodis pv. citri also may be able to produce xanthan. $X$. axonopodis pv. citri GumB protein (GenBank accession number NP_642899) shares 92\% amino acid identity with $X$. campestris pv. campestris GumB protein (GenBank accession number. YP_242744). Previously, it was shown that mutation of the gumB gene in $X$. campestris pv. campestris has a polar effect on gumB and gumC expression and that both gene products are required for the formation of xanthan from the pentasaccharide repeating unit (Vojnov et al. 1998).

We generated the $X$. axonopodis pv. citri gum mutant strain through allelic exchange mutagenesis, in which the functional gumB gene was replaced through homologous recombination with a copy containing a kanamycin-resistant $\left(\mathrm{Km}^{\mathrm{r}}\right)(\Omega)$ cassette. Disruption of the gumB gene in the mutant strain was confirmed by polymerase chain reaction (PCR) and Southern blot (data not shown). Extracellular polysaccharides were isolated from wild-type (WT) $X$. axonopodis pv. citri and gumB strains grown in peptone yeast and malt extract (PYM) medium supplemented with $2 \%$ glucose and quantified as described by Vojnov and associates (1998). Like X. campestris pv. campestris, X. axonopodis pv. citri synthesizes the EPS, xanthan, and releases it into the growth medium as a soluble polysaccharide. Large differences in EPS production were observed between WT $X$. axonopodis pv. citri strains $\left(8.2 \mathrm{~g} \mathrm{liter}^{-1}\right)$ and the gumB mutants $\left(0.15 \mathrm{~g} \mathrm{liter}^{-1}\right)$ after ethanol precipitation from the culture supernatant. Complementation of the gum mutant with the recombinant plasmid pIZD15-261, carrying the entire gum cluster of $X$. campestris pv. campestris (Vojnov et al. 1998, 2002), restores xanthan production to essentially the same level as in the $X$. axonopodis pv. citri WT (9.1 $\left.\mathrm{g} \mathrm{liter}^{-1}\right)$. Cultures of WT $X$. axonopodis pv. citri and the gumB mutant exhibit the same growth kinetics in PYM medium supplemented with $1 \%$ glucose (data not shown); thus, the mutant showed no loss of viability compared with WT $X$. axonopodis pv. citri.

\section{Bacterial attachment}

to abiotic and biotic surfaces and the role of xanthan.

In a preliminary assay, bacterial adhesion to polystyrene microtiter plates was analyzed by crystal violet staining. For these experiments, bacteria were grown overnight in PYM medium and then diluted into $\mathrm{Y}$ minimal medium. This assay detected no significant differences in the initial adhesion ( 1 to $3 \mathrm{~h}$ ) between the WT and gumB mutant (Fig. 1A). However, at $12 \mathrm{~h}$ or later, the culture of the gumB strain showed significantly less crystal violet staining that the WT (Fig. 1A). This suggests that EPS does play a role in biofilm development, particularly in later stages.

Bacterial adhesion to lemon leaves also was studied. Leaf disks were cut from healthy leaves and mounted onto petri dishes, adaxial side down. The disks were inoculated with $X$. axonopodis pv. citri WT and the gumB mutant strains and incubated at $28^{\circ} \mathrm{C}$. After $1,3,15$, and $24 \mathrm{~h}$ of incubation, the

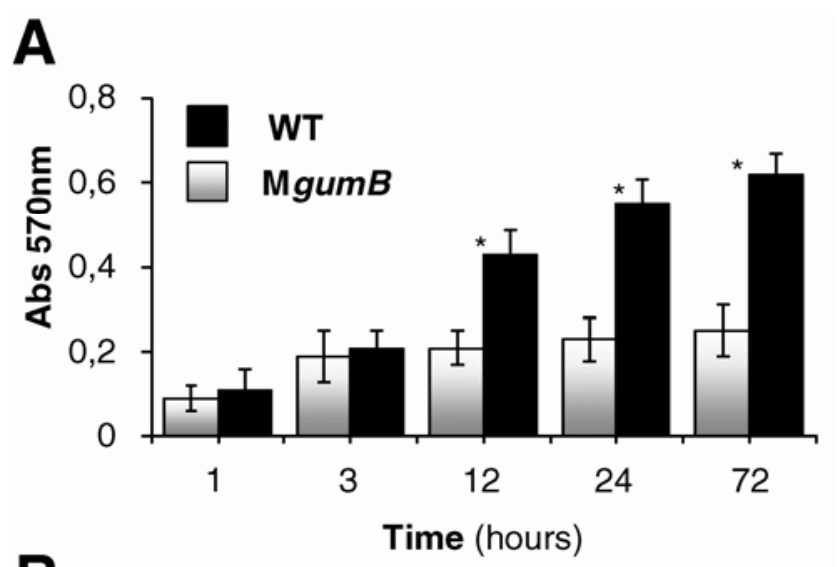

B
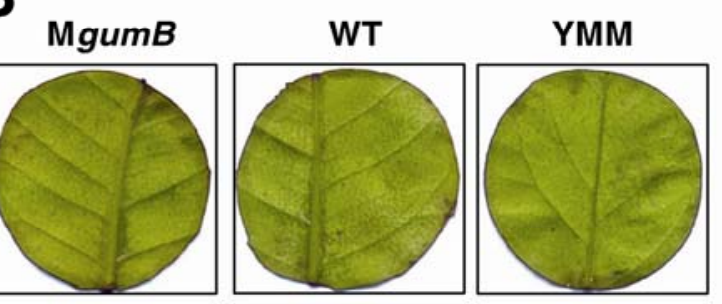

$1 \mathrm{~h}$
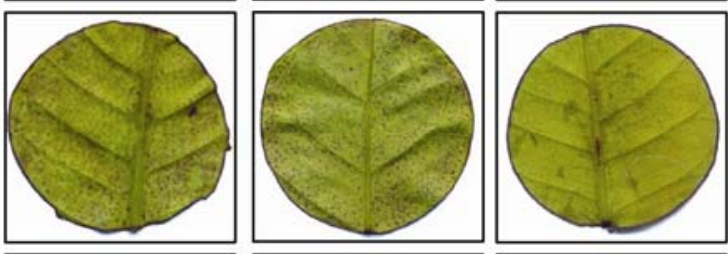

$3 \mathbf{h}$
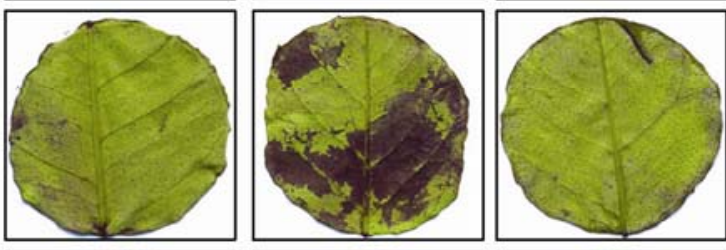

$15 \mathrm{~h}$
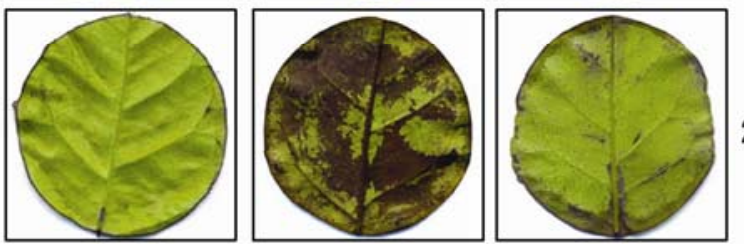

$24 \mathrm{~h}$

Fig. 1. Adhesion of Xanthomonas axonopodis pv. citri strains to abiotic and biotic surfaces. A, Bacterial adhesion and biofilm formation on inert plastic surface were assessed by the use of crystal violet at 1, 3, 12, 24, and $72 \mathrm{~h}$ of incubation. Values are expressed as means \pm standard deviation, $n=36$. Data set marked with an asterisk is significantly different as assessed by the Student's $t$ test, $P<0.05$. B, Bacterial adhesion and biofilm formation on abaxial surfaces of lemon leaves were assessed by the use of crystal violet at $1,3,15$, and $24 \mathrm{~h}$ of incubation. The stains attached cells to the leaf surface were analyzed macroscopically by the intensity of the blue dye. YMM = Y minimal medium. 
attached bacteria were revealed by crystal violet staining. The number of attached bacteria differed significantly after $15 \mathrm{~h}$ of incubation (Fig. 1B). No differential attachment was observed when growth of $X$. axonopodis pv. citri WT was compared with that of the $M g u m B$ mutant complemented by the entire gum cluster cloned into pIZD15-261 (data not shown).

\section{The $X$. axonopodis pv. citri WT strain forms structured} biofilms in vitro that require xanthan production.

In further experiments, we used inverted confocal laser scanning microscopy (CLSM) to analyze the biofilm structure developed by $X$. axonopodis pv. citri in vitro over a 4-day time course experiment in chambered cover slides. A green fluorescent protein (GFP)-labeled strain of $X$. axonopodis pv. citri was used to observe different stages of biofilm development at the bottom of chambered cover slides. A flat lawn of bacteria without any apparent microcolony or organized structure was observed in static cultures over the course of the experiment in PYM medium (data not shown). However, clear stages of bacterial biofilm development were observed for the $X$. axonopodis pv. citri WT strain grown on Y minimal medium containing $1 \%$ glucose. During initial attachment, bacteria often contacted the glass surface via one cell pole (Fig. 2, day 1). Attachment was followed by bacterial growth, likely accomplished through both cell division and cell migration. By days 3 and 4 of culture, isolated bacteria and single microcolonies were well established, and more complex structures had begun to form. These structures consisted of multiple layers of cells in contact with each other, predominantly through lateral interactions, though pole-to-pole interactions also were observed (Fig. 2). The architecture of the biofilm consisted of interconnected complex cell clustering similar to that of a honeycomb (Fig. 2, day 3).

In contrast, the gumB mutant labeled with GFP and grown on $\mathrm{Y}$ minimal medium containing $1 \%$ glucose failed to form microcolonies and complex structures after 4 days (Fig. 2). This distinct growth pattern was reproduced in four independent experiments. The whole gum cluster cloned in pIZD15-261 restored normal xanthan production in the gum mutant, as well as the mutant's ability to develop microcolonies, cell aggregates, and three-dimensional biofilm on the base of the chamber in static cultures (data not shown). These observations strongly suggest that biofilm formation in $X$. axonopodis pv. citri requires synthesis of xanthan.

\section{Biofilm and epiphytic fitness}

during $X$. axonopodis pv. citri-lemon plant interaction.

Formation of canker disease pustules may depend on how well bacteria attach and form biofilms on leaf surfaces. To examine the role of biofilm formation in canker disease, we examined the ability of Xanthomonas spp. to develop a biofilm on lemon leaves. Biofilm formation was monitored by CLSM over a 25-day period. GFP fluorescence was detected $24 \mathrm{~h}$ after spray inoculation on epidermal cells, and structures similar to the biofilms observed in vitro could be distinguished as early as 6 days postinoculation (dpi). $X$. axonopodis pv. citri cells were attached perpendicularly and horizontally and also were found distributed randomly on the lemon leaves (Fig. $3 \mathrm{~A})$. As we observed in the in vitro experiments, the xanthandeficient mutant grew as single cells and did not form microcolonies on lemon leaves during the length of the experiment, indicating that xanthan affects aggregate formation.

To evaluate the influence of biofilm formation on bacterial viability on plant leaves, we monitored the cell number on the leaf surfaces of Citrus limon for $10 \mathrm{dpi}$. By $24 \mathrm{~h}$ after inoculation, the epiphytic population of the WT had increased significantly and was nearly 100 times higher than for the gumB mutant (Fig. 3B). From that point forward, the population size of the WT remained approximately constant, whereas the numbers of $\operatorname{gumB}$ mutant bacteria declined slowly, so that, at $7 \mathrm{dpi}$, the difference in population size was three orders of magnitude (Fig. 3B).

\section{Canker development}

on lemon leaves is associated with biofilm formation.

To assess the importance of the ability to form biofilms on canker development, leaves were inoculated with bacterial suspensions of the WT and gumB mutant at a concentration of $10^{7}$

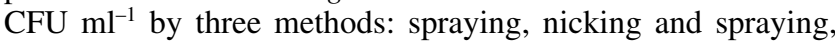
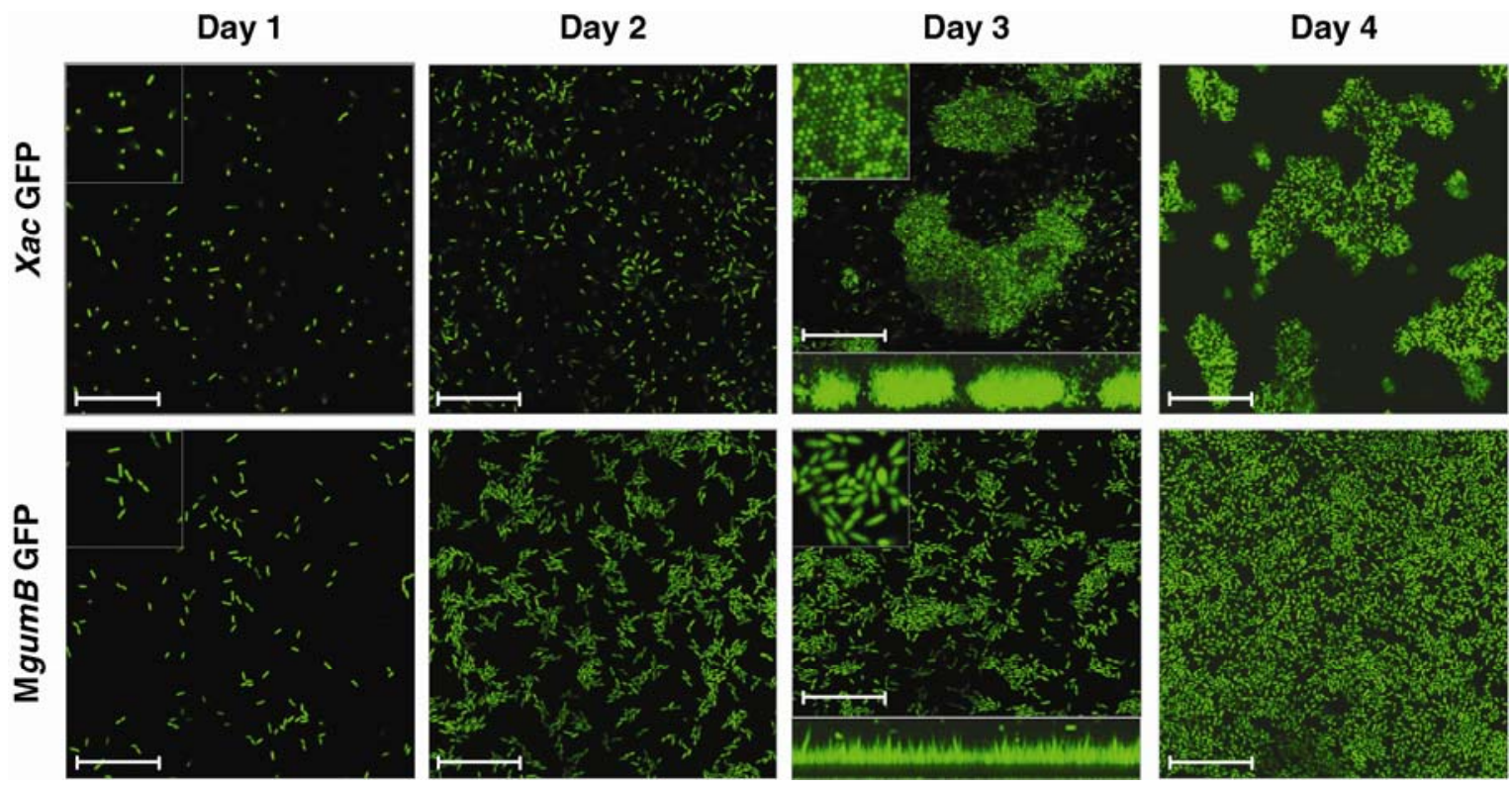

Fig. 2. Biofilm in wild-type and gumB mutant Xanthomonas axonopodis pv. citri strains. Green fluorescent protein (GFP)-labeled cells grown on chambered cover slides were visualized at different stages of the biofilm formation under confocal laser scanning microscopy for 4 days after inoculation. The panels (left to right) show cell attachment to the glass surface at $1.5 \mu \mathrm{m}$ from the base glass. The top inset for day 3 shows a detail of a typical wild-type $X$. axonopodis pv. citri (Xac) microcolony honeycomb structure and on the bottom, the biofilm on $x-z$ planes. Magnifications, $\times 1,000 ;$ zooms (inserts), $\times 4,000$. Scale bars, $20 \mu \mathrm{m}$. A minimum of four independent experiments was carried out for each strain, with essentially the same outcome. 
and pressure infiltration. Canker symptoms on lemon leaves 30 dpi are shown in Figure 4A. The gumB mutant was found to be severely compromised in its ability to cause canker disease in citrus using all three inoculation methods; although, in leaves subjected to pressure infiltration, the mutant showed slight water soaking around the infiltration site. Plants inoculated with $\mathrm{MgCl}_{2}$ showed no symptoms and the $\mathrm{MgumB}$ with the entire gum cluster cloned in pIZD15-261 restored the WT phenotype (Fig. 4A).

Comparison of the bacterial numbers in planta following inoculation via spraying revealed no significant differences between the WT and gumB mutant growth until 14 dpi, after which the population size of the gumB mutant growth showed no further increase. After $21 \mathrm{dpi}$, the population of the $g u m B \mathrm{mu}-$ tant began to decline and no mutant bacteria could be recovered after 5 weeks. In contrast, growth of the WT continued, so that

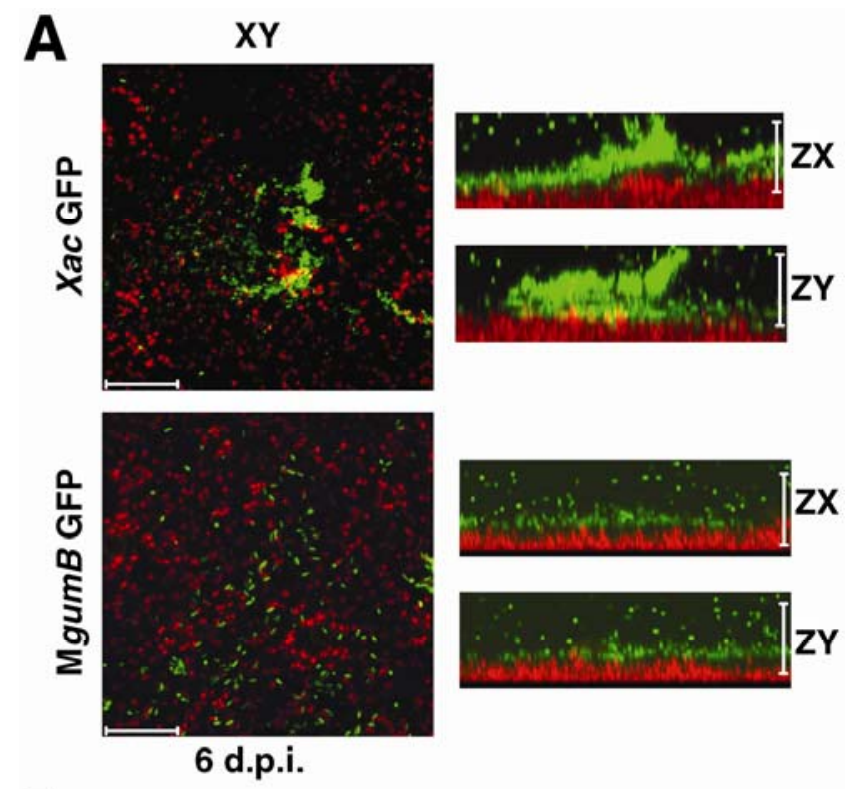

B

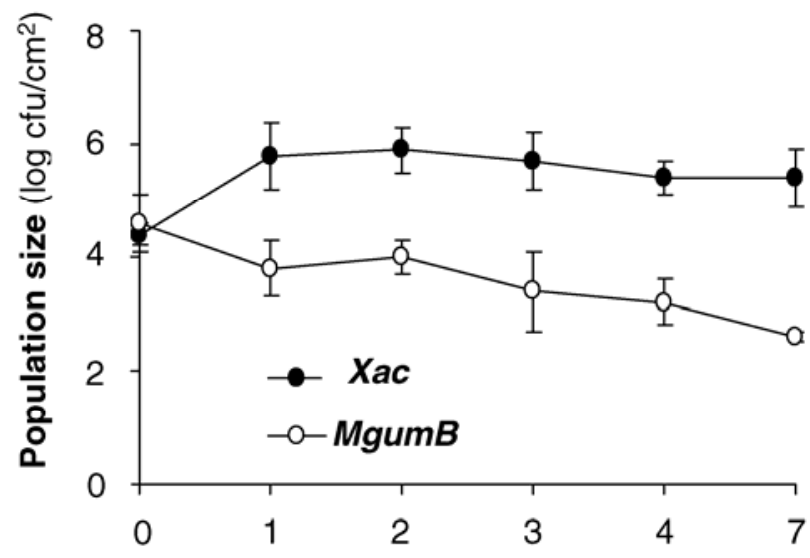

Days after inoculation

Fig. 3. Biofilm development and epiphytic growth on superficial panel leaf. A, Confocal laser scanning microscopy analysis of wild-type and gumB mutant. Bacterial suspensions were inoculated onto leaves surfaces using the spray method. $\mathrm{XY}, \mathrm{ZX}$, and $\mathrm{ZY}$ are the $\mathrm{XY}, \mathrm{ZX}$, and $\mathrm{ZY}$ axis projected images, respectively. Scale bars, $20 \mu \mathrm{m}$. B, Growth in vivo of epiphytic population of Xanthomonas axonopodis pv. citri (Xac) and the MgumB mutant on lemon leaves. Bacterial populations were determined by homogenizing the leaves in $\mathrm{MgCl}_{2}$ followed by dilution plating. Values are expressed as means \pm standard deviation. the population increased by more than six orders of magnitude over the 5-week monitoring period (Fig. 4B). Similar differences in behavior of WT and mutant bacteria were seen after pressure infiltration, with the exception that infiltration introduced a larger number of bacteria into the leaves than spraying (data not shown). Spray inoculation resembles natural inoculation (e.g., rain splash) more closely than either nicking or infiltrating.

We used CLSM with GFP-labeled X. axonopodis pv. citri cells to investigate whether bacteria were present within a biofilm structure during these canker developments on lemon leaves. The bacteria were monitored by CLSM over a 25-day period. In this analysis (Fig. 5), we were able to visualize aggregated bacteria within the developed canker. These aggregates of bacteria showed a three-dimensional structure with extensive water spaces redolent of the in vitro structure observed by CLSM analysis. Higher magnification of $X$. axonopodis pv. citri biofilms showed bacterial cells apparently embedded within an extracellular polymeric matrix, and aggregates appeared to be connected by this matrix. These aggregates were not seen with the gumB mutant bacteria, suggesting that EPS contributes to the structured architecture within cankers, which may provide an optimal environment for canker development.

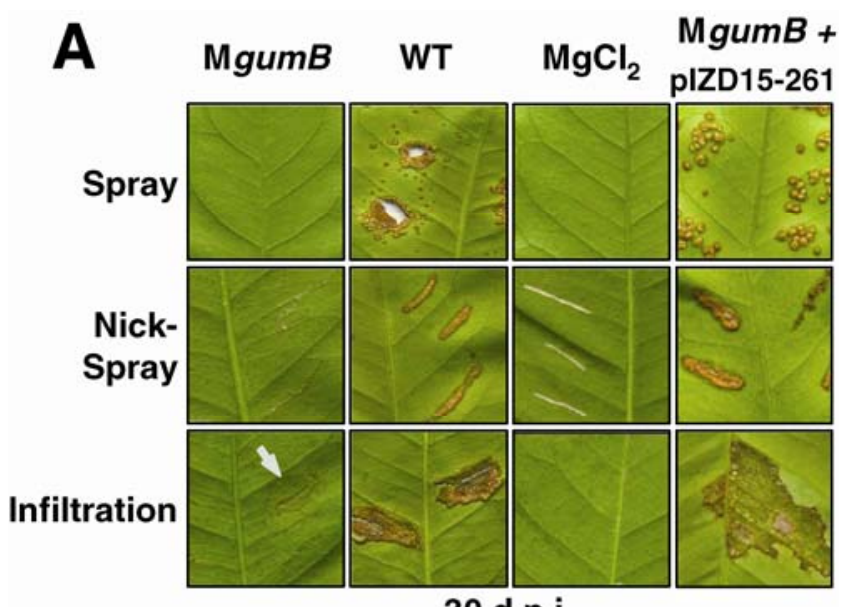

B

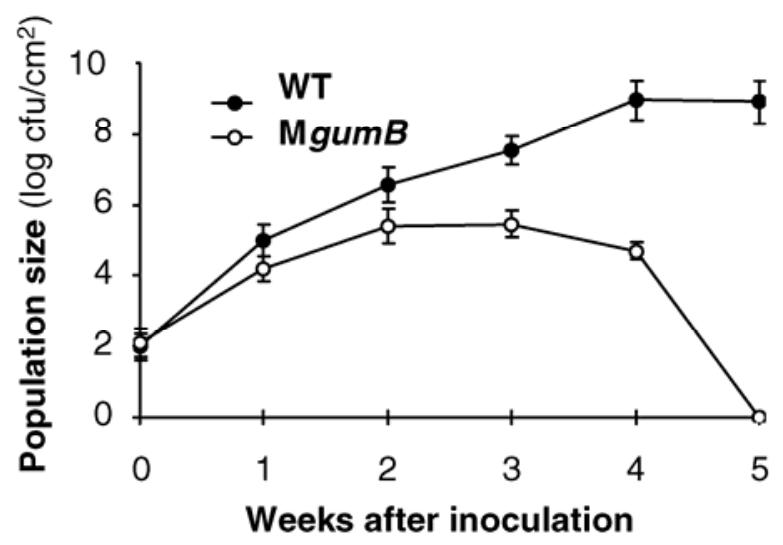

Fig. 4. Symptom development induced by Xanthomonas axonopodis pv. citri strains in Citrus limon. A, Macroscopic symptoms on lower surfaces of lemon leaves 30 days postinoculation (d.p.i.) with gumB mutant, the wild-type (WT) strains of Xanthomonas axonopodis pv. citri, and MgumB, with the entire gum cluster gene cloned in pIZD15-261 (MgumB + pIZD15-261). Bacterial suspensions were prepared in $10 \mathrm{mM} \mathrm{MgCl}_{2}$ solution and inoculated onto leaves surfaces using three different methods: spray, nick and spray; and pressure infiltration. B, Growth in vivo of $X$. axonopodis pv. citri strains on $C$. limon leaves. Values are expressed as means \pm standard deviation. 


\section{DISCUSSION}

We have analyzed the structure of $X$. axonopodis pv. citriproduced biofilms on different solid surfaces to gain insight into the dynamics of $X$. axonopodis pv. citri-host interactions in the development of citrus canker disease. Three stages of biofilm development were recognized: bacterial attachment, formation of aggregates or microcolonies, and finally the formation of structured biofilms within colonized leaves.

We have shown that the $X$. axonopodis pv. citri xanthan is essential for the formation of microcolonies and the subsequent development of more complex structures, in which bacteria are tightly packed in hexagonal arrays separated by water-filled channels (Figs. 2, 3, and 5). Such complex structures are found both in vitro and in planta. Similar phenotypes have been reported for the soil bacteria Rhizobium leguminosarum (Russo et al. 2006). These structures are remarkably different from the growth mode proposed for other species, including Pseudomonas aeruginosa, Rhodococcus rubber, and Proteus mirabilis, in which clonal growth occurs in the initial phase (mushroom stalks), followed by aggregation in later stages (mushroom caps) (Jones et al. 2007; Klausen et al. 2003; Sivan et al. 2006). Presumably, the diversity of biofilm architectures reflects the adaptation to specific microenvironments. Complex biofilm structure was not observed when $X$. axonopodis pv. citri bacteria were grown in the rich PYM medium (data not shown), suggesting that nutrient status is a critical factor in biofilm development.

Many biofilm matrix polysaccharide components of gramnegative bacteria have been reported to play important roles in biofilm physiology and persistence, such as colanic acid in Escherichia coli K-12 (Danese et al. 2000); alginate, Pel, and Pls in Pseudomonas aeruginosa (Jackson et al. 2004; Wozniak et al. 2003); alginate and levan in $P$. syringae (Laue et al. 2006); cellulose in Salmonella spp. and E. coli (Solano et al. 2002; Ude et al., 2006); and acidic EPS in Rhizhobium leguminosarum (Russo et al. 2006). Furthermore, X. campestris pv. campestris xanthan has been shown to be involved in biofilm formation in liquid medium (Crossman and Dow 2004; Dow et al. 2003). These EPSs are key elements that shape and provide structural support for bacterial biofilms.
The synthesis of EPS in many bacteria is under complex regulatory control. It has been demonstrated that synthesis of EPS is regulated by cell-to-cell signaling or quorum sensing in several phytopathogenic bacteria, including Pantoea stewartii (Koutsoudis et al. 2006), Pseudomonas syringae (Quinones et al. 2005), and Ralstonia solanacearum (Schell 2000), as well as X. campestris pv. campestris (Dow et al. 2000; Slater et al. 2000; Vojnov et al. 2001). Quorum sensing also can regulate expression of other factors or traits involved in virulence and epiphytic fitness (Chatterjee et al. 2007; Karamanoli and Lindow 2006; Quinones et al. 2004; Slater et al. 2000). In $X$. campestris pv. campestris, cell-to-cell signaling mediated by the diffusible signal factor controls biofilm dynamics, the synthesis of EPS, and the synthesis of extracellular enzymes (Crossman and Dow 2004; Dow et al. 2003; Slater et al. 2000). The synthesis of DSF depends upon RpfB and RpfF (Barber et al. 1997). DSF perception and signal transduction is believed to involve the sensor kinase $\mathrm{RpfC}$ and cognate response regulator RpfG and is linked to the degradation of the intracellular signaling molecule, cyclic di-GMP, through the HD-GYP domain of RpfG (Ryan et al. 2006). Recently, we provided evidence that $r p f / D S F$ system also is involved in controlling virulence factor synthesis in $X$. axonopodis pv. citri (Siciliano et al. 2006), suggesting that cell-to-cell signaling plays a role in canker pathogenicity. The mechanism or mechanisms through which cyclic di-GMP influences the synthesis of xanthan is currently obscure. The rpf/DSF system appears to regulate of the expression of the gum operon at the transcriptional level (Vojnov et al. 2001). Although this suggests that cyclic diGMP may influence transcription, we cannot exclude the possibility that the nucleotide exerts post-translational effects; for example, on the activity of GumB or other proteins involved in xanthan synthesis.

The presence of plant-associated biofilms is correlated with $X$. axonopodis pv. citri pathogenicity, which was severely attenuated by the disruption of a single gene involved in the biosynthesis of EPS, gumB (Fig. 4). Xanthan-deficient mutants of various xanthomonads show reduced virulence compared with WT bacteria in numerous studies (Chou et al. 1997; Dharmapuri and Sonti 1999; Katzen et al. 1998; Kemp et al. 2004; Li et al.

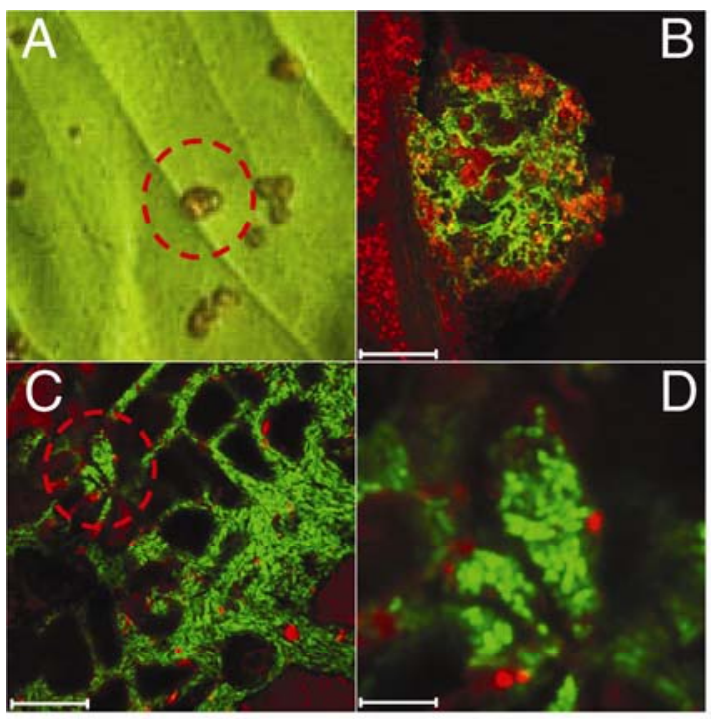

B

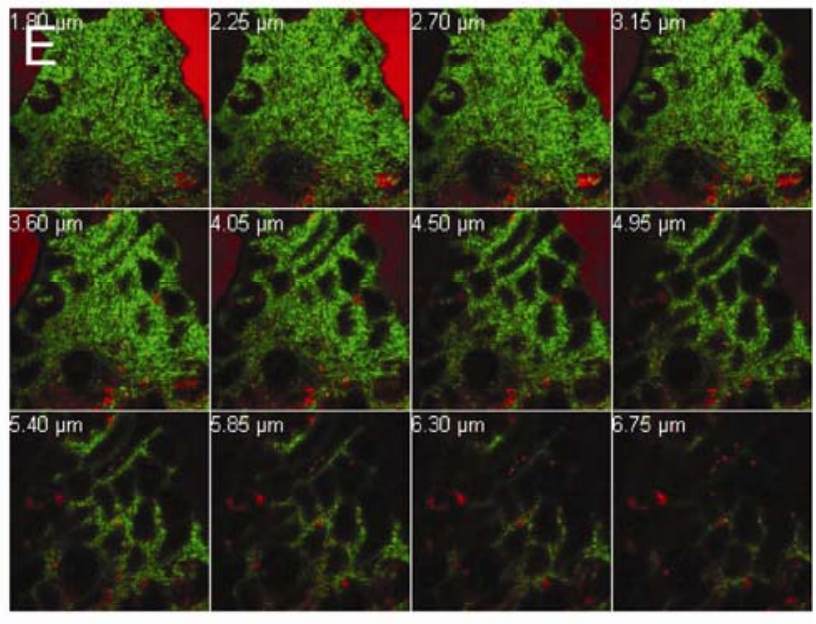

25 d.p.i

Fig. 5. Real-time imaging of the canker development on lemon leaves. A, Green fluorescent protein (GFP) fluorescence from wild-type (WT) Xanthomonas axonopodis pv. citri strain within a canker pustule was detected by confocal laser scanning microscopy. Each picture shows the analyzed canker and the distribution of GFP-labeled bacteria within the pustule at $\mathbf{B}, \times 100, \mathbf{C}, \times 1,000$, and $\mathbf{D}, \times 4,000$. Scale bars are $\mathbf{B}, 200 \mu \mathrm{m}, \mathbf{C}, 20 \mu \mathrm{m}$, and $\mathrm{D}, 5 \mu \mathrm{m}$. Areas within the dotted red lines of panels A and C are shown enlarged in panels B and D, respectfully. E, WT GFP-labeled X. axonopodis pv. citri in a canker pustule showed at different distances from the base. Scale bars, $20 \mu \mathrm{m}$. 
2001; Newman et al. 1994; Yun et al. 2006). In contrast, a recent report indicates that the $X$. axonopodis pv. citri gumD gene, although contributing to epiphytic survival, is not involved in pathogenesis (Dunger et al. 2007), challenging previous findings and arguing against the role of xanthan in the virulence of $X$. axonopodis pv. citri. Differences in experimental approach perhaps could account for these divergent conclusions about the role of xanthan in $X$. axonopodis pv. citri-Citrus spp. interactions. Such differences occur in the plant host $(C$. sinensis versus $C$. limon) and WT isolates of $X$. axonopodis pv. citri used, in the mutations used to generate the xanthan-minus $X$. axonopodis pv. citri strains, and in the inoculation procedures.

It is difficult to determine whether the difference in aggressiveness of $X$. axonopodis pv. citri strains is affected by the strategy used to generate xanthan deficiency. Dunger and associates (2007) generated a xanthan-deficient mutant by a deletion part of the gumD gene, which encodes a glycosyltransferase involved in synthesis of the first xanthan lipid intermediate. The $X$. axonopodis pv. manihotis gumD gene was shown to be essential for EPS production and pathogenicity and contributes to epiphytic fitness on the host plant (Kemp et al. 2004). In contrast, our study generated a xanthan-deficient strain through mutation of the gumB gene. The gumB protein polymerizes a pentasaccharide intermediate into mature xanthan (Vojnov et al. 1998). In X. campestris pv. campestris, gumB mutants produce no xanthan, show reduced virulence (Chou et al. 1997; Katzen et al. 1998; Li et al. 2001), and fail to grow when inoculated into leaves of Brassica campestris, Nicotiana benthamiana, and Arabidopsis thaliana (Newman et al. 1994; Yun et al. 2006). One difference between the use of gumB and gumD mutants would be in the accumulation of the pentasaccharide lipid intermediate in the former compared with the lipid alone in the latter. Although it is possible that this pentasaccharide lipid has some negative effects on additional cellular functions that contribute to virulence, we consider this unlikely because the gumB mutation had no effect on $X$. axonopodis pv. citri growth, and studies in $X$. campestris pv. campestris have shown that the level of the pentasaccharide lipid intermediate is much lower in the gumB mutant than in the WT (Vojnov et al. 1998). Intriguingly, in Xylella fastidiosa, the disruption of the $\operatorname{gumB}$ gene does not significantly alter production of the EPS fastidian, but mutants do show a reduced capacity to form biofilms (Souza et al. 2006).

A second significant experimental difference is in the inoculation methods. In our experiments, the loss of pathogenicity was especially evident following spray and nick-spray infection, in which the gumB mutant failed to induce any symptoms. Spray and nick-spray methods mimic Xanthomonas axonopodis pv. citri entry in vivo, in which invasion of host mesophyll is accomplished through natural openings such as stomata and through lesions. In contrast, the findings of Dunger and associates (2007) are based on two methods that do not mimic natural processes. The first method, pressure infiltration, serves to mechanically destroy the primary physical barriers in plant defense: the cuticle and cell wall. For this reason, $X$. axonopodis pv. citri gumB mutants that are pressure infiltrated are more capable of causing canker symptoms than mutants inoculated via spray or nick and spray (Fig. 4A). The second methodspray-inoculation of bacteria in the presence of Silwet L-77is likely to have the same effect as pressure infiltration. Silwet L-77 is a surface-active agent that lowers surface tension. It is used to facilitate penetration of bacteria into plant tissues (Wu et al. 2003), but likely allows for partial infiltration of the leaf. Finally, the discrepancy between our results and those of Dunger and associates (2007) could reflect differences in the species of Citrus employed as a host and in the WT X. axonopodis pv. citri strains used. Perhaps the contribution of differ- ent factors contributing to virulence varies quantitatively in different $X$. axonopodis pv. citri-Citrus spp. interactions.

Based upon our results, the ability of $X$. axonopodis pv. citri to develop a biofilm that induces canker disease in citrus suggests that a biofilm lifestyle is a natural environment for $X$. axonopodis pv. citri and that extracellular components are particularly relevant. Living within a biofilm could offer many advantages to $X$. axonopodis pv. citri in comparison with the planktonic state; the biofilm can act as a defense or survival mechanism, or it can facilitate cell-to-cell communication and growth in the poor nutrient-leaf environment. In addition, the growth of the bacteria within biofilms has been shown to generate a large amount of genetic diversity (Boles et al. 2004), which would allow the bacterial community to adapt to sudden environmental changes better than if the populations were genetically homogenous.

Our results indicate that xanthan plays an important role in the formation of biofilms and in bacterial survival on the leaf. Without xanthan, the bacteria are unable to retain water and cannot withstand abiotic stress and, thus, cannot survive on the leaf surface. Bacterial colonization also is required for expression of virulence-associated genes that induce plant defenses (Marco et al. 2005). The role of xanthan in both pathogen virulence and host defense may explain why smaller epiphytic bacterial populations were observed for the mutant compared with WT (Fig. 3B). However, other roles played by xanthan in disease development should not be ruled out. For example, EPS has been shown to mediate suppression of plant defense reactions (D'Haeze and Holsters 2004; Yun et al. 2006), and EPS can act as a specific recognition signal in human cells (Bylund et al. 2006).

Further studies on the temporal and spatial regulation of xanthan production in canker development, as well as studies to understand other regulatory mechanisms of gene expression involved in biofilm formation, should advance our understanding of the adaptation of bacteria to parasitic life within plants. Such knowledge may provide a rational basis for the development of crop protection methods based on interference with key processes in the epiphytic and disease phases of bacterial pathogenesis.

\section{MATERIALS AND METHODS}

\section{Bacterial strains and culture conditions.}

The WT strain of $X$. axonopodis pv. citri was described previously (Siciliano et al. 2006). Xanthomonas strains were grown at $28^{\circ} \mathrm{C}$ in PYM nutrient medium (Siciliano et al. 2006). For analysis of biofilm development, bacteria were grown in $\mathrm{Y}$ minimal medium containing glucose $\left(1 \% \mathrm{wt} \mathrm{vol}^{-1}\right)$ as the carbon source (Sherwood 1970). E. coli was grown at $37^{\circ} \mathrm{C}$ in Luria-Bertani medium (Sambrook et al. 1989). Bacterial growth was measured in a Spectronic 20Genesys spectrophotometer (Thermo Electron Corporation, Boston) at $600 \mathrm{~nm}$. When required, the antibiotics kanamycin and gentamicin were added to the growth media at concentrations of 50 and 10 $\mu \mathrm{g} \mathrm{ml}^{-1}$, respectively.

\section{Site-directed gene replacement of $X$. axonopodis pv. citri.}

The molecular techniques used in this study were based on protocols described previously (Sambrook et al. 1989). Genomic DNA from the $X$. axonopodis pv. citri strain was extracted according to Chen and Kuo (1993). From the region encoding the WT $X$. axonopodis pv. citri gumB and gumC genes, 1,457-bp fragments were PCR amplified using the primer pairs AGTTA CGTGTTGGCGATCTTGGC (sense) and AATGGCGTGCGG TCTCTTTC (antisense), designed from $X$. axonopodis pv. citri sequences available in GenBank (AE008923) (da Silva et al. 
2002). Each 50- $\mu$ l PCR reaction consisted of $0.2 \mu \mathrm{M}$ each primer, $1 \times$ PCR buffer, $1.5 \mathrm{mM} \mathrm{MgCl} 2,0.2 \mathrm{mM}$ dNTPs, $75 \mathrm{ng}$ DNA $\mu \mathrm{l}^{-1}$, and $1 \mathrm{U}$ of Taq DNA polymerase (Invitrogen, Carlsbad, CA, U.S.A.). PCR amplifications were performed with a Mastercycler (Eppendorf, Hamburg, Germany) using the following conditions $\left(35\right.$ cycles): $95^{\circ} \mathrm{C}$ for $60 \mathrm{~s}, 63^{\circ} \mathrm{C}$ for $30 \mathrm{~s}$, and $72^{\circ} \mathrm{C}$ for $90 \mathrm{~s}$. All PCR reactions were started with an initial denaturation step of $10 \mathrm{~min}$ at $95^{\circ} \mathrm{C}$ and a single final extension cycle at $72^{\circ} \mathrm{C}$ for $10 \mathrm{~min}$. The PCR products were resolved in a $0.8 \%$ agarose gel electrophoresis (Sambrook et al. 1989). The corresponding band was excised and gel purified using the Qiaex II gel extraction kit (Qiagen, Valencia, CA, U.S.A.) and cloned into pGEM-Teasy vector (Promega, Madison, WI, U.S.A.) to produce pLR-XB. The gumB-C fragment contains a cleavage site for restriction enzyme BamHI. The 2$\mathrm{kb}$ fragment containing the $\mathrm{Km}^{\mathrm{r}}(\Omega)$ cassette from $\mathrm{pAZ}(\Omega)$ (kindly provided by Dr. Angeles Zorreguieta, Fundación Instituto Leloir, Buenos Aires, Argentina) was inserted in the gumB cleavage site, BamHI, generating a disrupted copy of the gumB gene. These constructs were digested with NotI and subcloned into the suicide vector, pJQ200KS (Muller et al. 1993). The generating pSac-EPS plasmid was transformed into WT $X$. axonopodis pv. citri by electroporation (Guilhabert et al. 2001). Transformed bacteria were selected on PYM nutriet medium solidified with $1.5 \%(\mathrm{wt} / \mathrm{vol})$ agar, kanamycin at 50 $\mu \mathrm{g} \mathrm{ml}{ }^{-1}$, and 5\% sacarose (Muller et al. 1993). Disruption of the gumB locus in the mutant strain $\operatorname{gumB}:: \mathrm{Km}^{\mathrm{r}}$ was confirmed by PCR and Southern blot (data not shown). Isolated mutant was screened for EPS synthesis by precipitation of xanthan from the culture supernatant (Vojnov et al. 1998, 2002).

\section{Assay for xanthan production.}

For measurements of xanthan production, strains were grown in PYM medium supplemented with $2 \%$ D-glucose at $28^{\circ} \mathrm{C}$ for $24 \mathrm{~h}$ with shaking. EPS was precipitated from culture supernatants by ethanol, dried, and weighed as described by Vojnov and associates (1998).

\section{Plant preparation and pathogenicity assays.}

Lemon plants $(C$. limon cv. Eureka) were grown as previously reported (Siciliano et al. 2006). All plant inoculations involved a minimum of three leaves from each plant and three plants were inoculated for each strain of Xanthomonas tested. Inoculations of bacteria into the lamina of young lemon leaves were done according to published methods (Siciliano et al. 2006). Bacterial suspensions of $X$. axonopodis pv. citri, $X$. axonopodis pv. citri mutant, and $\mathrm{MgumB}+\operatorname{pIZD15-261~}\left(10^{7}\right.$ $\mathrm{CFU} \mathrm{ml} l^{-1}$ in $10 \mathrm{mM} \mathrm{MgCl}_{2}$ ) were inoculated by pressure infiltration, nick and spray, and spray alone. $\mathrm{MgCl}_{2}$ was used as control of noninfected leaves. Inoculated plants were maintained for 25 to 30 days in a growth cabinet, with temperatures ranging from 25 to $28^{\circ} \mathrm{C}$, high humidity, a photoperiod of $16 \mathrm{~h}$ of light, and a light intensity of 150 to $200 \mu \mathrm{E} \mathrm{sm}{ }^{-2}$. Disease progression was monitored phenotypically in three separate biological assays and through analysis of bacterial growth curves.

\section{Isolation of bacterial strains.}

Bacterial populations were isolated from the leaves according to the method described by Siciliano and associates (2006). Three leaf disks of $1 \mathrm{~cm}^{2}$ were selected randomly from the inoculated leaves. The disks were immersed in $500 \mu \mathrm{l}$ of $10 \mathrm{mM}$ $\mathrm{MgCl}_{2}$ in Eppendorf microfuge tubes. Bacterial cells were collected by homogenization of tissue with a plastic pestle. The suspension was stirred at room temperature for $5 \mathrm{~min}$ and serial dilutions of this suspension were plated on PYM agar plates to estimate the size of the total bacterial population. Leaf samples were taken once a week to determine bacterial population sizes on the leaves. At each time point, samples were determined from three separate experiments and each experiment was measured in triplicate.

For determination of epiphytic survival, bacterial populations were isolated from the leaves according to the method described by Morris and associates (1998). Epiphytic bacterial numbers were determined as above, but leaf disks were stirred gently at room temperature for 2 min to release bacteria on the surface of the leaves without liberating bacteria within the cellular apoplast. The experiment was repeated once a day for 1 week to determine epiphytic survival on lemon leaves. At each time point, samples were taken from three separate plants and each experiment was measured in triplicate.

\section{Microscopy and image of the dynamic of biofilm development.}

Inverted CLSM was used for the study of biofilms both in vitro and in vivo. For the in vitro study, biofilm formation assays in chambered coverglass slides containing a borosilicate glass $1 \mu \mathrm{m}$ thick (no. 155411; Lab-Tek, Nunc, Naperville, IL, U.S.A.) were performed as described previously (Russo et al. 2006). Each strain was transformed by triparental mating, with plasmid pMP2444 expressing the GFP (Stuurman et al. 2000). The $g f p$-expressing bacterial strains were grown overnight on Y minimal medium supplemented with $1 \%$ glucose containing the appropriate antibiotics at $28^{\circ} \mathrm{C}$ (Sherwood 1970). Bacterial cultures were diluted 1:1000 and grown in chambers without shaking at $28^{\circ} \mathrm{C}$ for 7 days. To prevent desiccation, the chambers were incubated in a humid sterile petri dish. Briefly, for the in vivo study, leaves of $C$. limon were infected by spray, as described above, with GFP-labeled bacterial suspension of $X$. axonopodis pv. citri WT and the mutant strain gumB $:: \mathrm{Km}^{\mathrm{r}}$. Plants were incubated in the same conditions described above until canker formation. Areas of approximately $1 \mathrm{~cm}^{2}$ were cut from the leaves and mounted on the adaxial leaf surface under glass coverslips.

Bacterial growth on both abiotic and biotic surfaces were examined with an inverted confocal microscope (LSM510Axiovert 100M; Carl Zeiss, Oberkochen, Germany). Simulated three-dimensional images and sections were generated by using the Zeiss LSM Image Browser, version 3.2.0. Canker development by bacteria carrying the plasmid pMP2444 was similar to $X$. axonopodis pv. citri. No difference in growth or biofilm formation could be detected using (nonfluorescence) microscopy of biofilms formed by bacteria containing or lacking the GFP plasmid.

\section{Bacterial adhesion study.}

To analyze the function of EPS production on initial attachment and biofilm formation, we used the microplate colorimetric assay involving crystal violet staining of biofilms (Davey and O'Toole 2000). X. axonopodis pv. citri WT and the mutant strain gumB:: $\mathrm{Km}^{\mathrm{r}}$ were grown in wells of polystyrene 96-well flat-bottom tissue culture plates (Corning Incorporated, Corning, NY, U.S.A.) as follows. Bacteria were grown overnight in PYM medium, then inoculated into $Y$ medium at a 1:1000 dilution (Sherwood 1970). Once the X. axonopodis pv. citri cultures reached an optical density at $600 \mathrm{~nm}$ of $0.1 \mathrm{in} \mathrm{Y} \mathrm{minimal}$ medium, aliquots of $100 \mu \mathrm{l}$ were placed into the wells of microtiter plates and incubated at $28^{\circ} \mathrm{C}$ for different lengths of times (Fig. 1A). After incubation, the medium was gently removed using a pipette, microtiter plate wells were washed three times gently with $150 \mu \mathrm{l}$ of sterile distilled water, and the bacteria attached to the surface was incubated at $60^{\circ} \mathrm{C}$ for 20 min. The amount of surface-attached biofilm was determined using $150 \mu \mathrm{l}$ of $0.30 \%$ (wt vol ${ }^{-1}$ ) crystal violet (Acros Organics, Geel, Belgium) (Davey and O'Toole 2000) for $45 \mathrm{~min}$ at room 
temperature. The unbound crystal violet stain was removed using a pipette, and the wells were washed gently three times with $150 \mu$ l of sterile distilled water. The crystal violet in each well was solubilized by adding $100 \mu$ of acetone-ethanol ( $20 \%$ acetone). The biofilm cell-associated dye was measured by absorption at $570 \mathrm{~nm}$ using a microtiter plate reader (PowerWave XS; Bio-Tek, Winooski, VT, U.S.A.). Readings from 36 independent experiments were averaged. To compare the adherence between strains, we used the statistic analysis Student's $t$ test $(P<0.05)$.

Bacterial adhesion also was studied on lemon leaves. $X$. axonopodis pv. citri WT and the mutant strain gumB:: $\mathrm{Km}^{\mathrm{r}}$ were grown in the same conditions described for the microplate colorimetric assay. Leaf disks of approximately $35 \mathrm{~mm}^{2}$ were cut from healthy leaves and mounted onto petri dishes, adaxial side down. Leaf disks were inoculated with $3 \mathrm{ml}$ of the bacterial suspension at a concentration of $10^{7} \mathrm{CFU} \mathrm{ml^{-1 }}$ and incubated at $28^{\circ} \mathrm{C}$. After $1,3,15$, and $24 \mathrm{~h}$ of incubation, the leaf disks were rinsed three times with distilled water. The adhered bacteria on the leaf surface were warmed at $60^{\circ} \mathrm{C}$ for $20 \mathrm{~min}$. The amount of surface-attached biofilm in vivo was determined using $3 \mathrm{ml}$ of $0.30 \%$ crystal violet for $45 \mathrm{~min}$ at room temperature. The unbound crystal violet stain was removed and the leaf disks were washed gently three times with distilled water. The stains attached cells to the leaf surface that were analyzed macroscopically by the intensity of the blue dye.

\section{ACKNOWLEDGMENTS}

The work was supported by the Agencia de Promoción Científica y Tecnológica (PICT-02 no. 08-10740; PAV-137) and Consejo Nacional de Investigaciones Científicas y Técnicas (CONICET, PIP6441). M. R. Marano, A. A. Vojnov, and A. P. Castagnaro are Career Investigators of the CONICET. We thank M. Richey for critically reading the manuscript. We also thank A. Zorreguieta for providing $\mathrm{pAZ}(\Omega)$ and helping with the confocal microscopy. We are grateful to T. S. Coloma for making available the confocal microscope.

\section{LITERATURE CITED}

Barber, C. E., Tang, J. L., Feng, J. X., Pan, M. Q., Wilson, T. J., Slater, H., Dow, J. M., Williams, P., and Daniels, M. J. 1997. A novel regulatory system required for pathogenicity of Xanthomonas campestris is mediated by a small diffusible signal molecule. Mol. Microbiol. 24:555-566.

Boles, B. R., Thoendel, M., and Singh, P. K. 2004. Self-generated diversity produces "insurance effects" in biofilm communities. Proc. Natl. Acad. Sci. U.S.A. 101:16630-16635.

Branda, S. S., Vik, S., Friedman, L., and Kolter, R. 2005. Biofilms: the matrix revisited. Trends Microbiol. 13:20-26.

Brunings, A. M., and Gabriel, D. W. 2003. Xanthomonas citri: breaking the surface. Mol Plant Pathol. 4:141-157.

Bylund, J., Burgess, L. A., Cescutti, P., Ernst, R. K., and Speert, D. P. 2006. Exopolysaccharides from Burkholderia cenocepacia inhibit neutrophil chemotaxis and scavenge reactive oxygen species. J. Biol. Chem. 281:2526-2532.

Camilli, A., and Bassler, B. L. 2006. Bacterial small-molecule signaling pathways. Science 311:1113-1116.

Chatterjee, A., Cui, Y., Hasegawa, H., and Chatterjee, A. K. 2007. PsrA, Pseudomonas sigma regulator, controls regulators of epiphytic fitness, quorum sensing signal and plant interaction in Pseudomonas syringae pv. tomato strain DC3000. Appl. Environ. Microbiol. 73:3684-3694.

Chen, W. P., and Kuo, T. T. 1993. A simple and rapid method for the preparation of gram-negative bacterial genomic DNA. Nucleic Acids Res. 21:2260.

Chou, F. L., Chou, H. C., Lin, Y. S., Yang, B. Y., Lin, N. T., Weng, S. F., and Tseng, Y. H. 1997. The Xanthomonas campestris gumD gene required for synthesis of xanthan gum is involved in normal pigmentation and virulence in causing black rot. Biochem. Biophys. Res. Commun. 233:265-269.

Costerton, J. W., Stewart, P. S., and Greenberg, E. P. 1999. Bacterial biofilms: a common cause of persistent infections. Science 284:13181322.

Crossman, L., and Dow, J. M. 2004. Biofilm formation and dispersal in Xanthomonas campestris. Microbes Infect. 6:623-629.
Cubero, J., and Graham, J. H. 2004. The leucine-responsive regulatory protein (lrp) gene for characterization of the relationship among Xanthomonas species. Int. J. Syst. Evol. Microbiol. 54:429-437.

Danese, P. N., Pratt, L. A., and Kolter, R. 2000. Exopolysaccharide production is required for development of Escherichia coli K-12 biofilm architecture. J. Bacteriol. 182:3593-3596.

da Silva, A. C., Ferro, J. A., Reinach, F. C., Farah, C. S., Furlan, L. R., Quaggio, R. B., Monteiro-Vitorello, C. B., Van Sluys, M. A., Almeida, N. F., Alves, L. M. C, do Amara, A. M., Bertolini, M. C., Camargo, L. E. A, Camarotte, G., Cannavan, F., Cardozo, J., Chambergo, F., Ciapina, L. P., Cicarelli, R. M. B., Coutinho, L. L., Cursino-Santos, J. R., ElDorry, H., Faria, J. B., Ferreira, A. J. S., Ferreira, R. C. C., Ferro, M. I. T., Formighieri, E. F., Franco, M. C., Greggio, C. C., Gruber, A., Katsuyama, A. M., Kishi, L. T., Leite, R. P., Lemos, E. G. M., Lemos, M. V. F., Locali, E. C., Machado, M. A., Madeira, A. M. B. N., MartinezRossi, N. M., Martins, E. C., Meidanis, J., Menck, C. F. M., Miyaki, C. Y., Moon, D. H., Moreira, L. M., Novo, M. T. M., Okura, V. K., Oliveira, M. C., Oliveira, V. R., Pereira, H. A., Rossi, A., Sena, J. A. D., Silva, C., de Souza, R. F., Spinola, L. A F., Takita, M. A., Tamura, R. E., Teixeira, E. C., Tezza, R. I. D., Trindade dos Santos, M., Truffi, D., Tsai S. M., White F. F., Setubal J. C., and Kitajima, J. P. 2002. Comparison of the genomes of two Xanthomonas pathogens with differing host specificities. Nature 417:459-463.

Davey, M. E., and O'Toole, G. A. 2000. Microbial biofilms: from ecology to molecular genetics. Microbiol. Mol. Biol. Rev. 64:847-867.

D'Haeze, W., and Holsters, M. 2004. Surface polysaccharides enable bacteria to evade plant immunity. Trends Microbiol. 12:555-561.

Dharmapuri, S., and Sonti, R. V. 1999. A transposon insertion in the gumG homologue of Xanthomonas oryzae pv. oryzae causes loss of extracellular polysaccharide production and virulence. FEMS (Fed. Eur. Microbiol. Soc.) Microbiol. Lett. 179:53-59.

Dow, J. M., Feng, J. X., Barber, C. E., Tang, J. L., and Daniels, M. J. 2000. Novel genes involved in the regulation of pathogenicity factor production within the rpf gene cluster of Xanthomonas campestris. Microbiology 146:885-891.

Dow, J. M., Crossman, L., Findlay, K., He, Y. Q., Feng, J. X., and Tang, J. L. 2003. Biofilm dispersal in Xanthomonas campestris is controlled by cell-cell signaling and is required for full virulence to plants. Proc. Natl. Acad. Sci. U.S.A. 100:10995-11000.

Dunger, G., Relling, V. M., Tondo, M. L., Barreras, M., Ielpi, L., Orellano, E. G., and Ottado, J. 2007. Xanthan is not essential for pathogenicity in citrus canker but contributes to Xanthomonas epiphytic survival. Arch. Microbiol. 188:127-135.

Fujishige, N. A., Kapadia, N. N., De Hoff, P. L., and Hirsch, A. M. 2006. Investigations of Rhizobium biofilm formation. FEMS (Fed. Eur. Microbiol. Soc.) Microbiol. Ecol. 56:195-206.

Guilhabert, M. R., Hoffman, L. M., Mills, D. A., and Kirkpatrick, B. C. 2001. Transposon mutagenesis of Xylella fastidiosa by electroporation of Tn5 synaptic complexes. Mol. Plant-Microbe Interact. 14:701-706.

Hirano, S. S., and Upper, C. D. 1983. Ecology and epidemiology of foliar bacterial plant pathogens. Annu. Rev. Phytopathol. 21:243-269.

Jackson, K. D., Starkey, M., Kremer, S., Parsek, M. R., and Wozniak, D. J. 2004. Identification of $p s l$, a locus encoding a potential exopolysaccharide that is essential for Pseudomonas aeruginosa PAO1 biofilm formation. J. Bacteriol. 186:4466-4475.

Jansson, P. E., Kenne, L., and Lindberg, B. 1975. Structure of extracellular polysaccharide from Xanthomonas campestris. Carbohydr. Res. 45:275282.

Jones, S. M., Yerly, J., Hu, Y., Ceri, H., and Martinuzzi, R. 2007. Structure of Proteus mirabilis biofilms grown in artificial urine and standard laboratory media. FEMS (Fed. Eur. Microbiol. Soc.) Microbiol. Lett. 268:16-21.

Kang, Y., Saile, E., Schell, M. A., and Denny, T. P. 1999. Quantitative immunofluorescence of regulated eps gene expression in single cells of Ralstonia solanacearum. Appl. Environ. Microbiol. 65:2356-2362.

Karamanoli, K., and Lindow, S. E. 2006. Disruption of N-acyl homoserine lactone-mediated cell signaling and iron acquisition in epiphytic bacteria by leaf surface compounds. Appl. Environ. Microbiol. 72:7678-7686.

Katzen, F., Ferreiro, D. U., Oddo, C. G., Ielmini, M. V., Becker, A., Puhler, A., and Ielpi, L. 1998. Xanthomonas campestris pv. campestris gum mutants: effects on xanthan biosynthesis and plant virulence. J. Bacteriol. 180:1607-1617.

Kemp, B. P., Horne, J., Bryant, A., and Cooper, R. M. 2004. Xanthomonas axonopodis pv. manihotis gumD gene is essential for EPS production and pathogenicity and enhances epiphytic survival on cassava (Manihot esculente). Physiol. Mol. Plant Pathol. 64:209-218.

Klausen, M., Aaes-Jorgensen, A., Molin, S., and Tolker-Nielsen, T. 2003. Involvement of bacterial migration in the development of complex multicellular structures in Pseudomonas aeruginosa biofilms. Mol. Microbiol. 50:61-68. 
Kolter, R., and Greenberg, E. P. 2006. Microbial sciences: the superficial life of microbes. Nature 441:300-302.

Koutsoudis, M. D., Tsaltas, D., Minogue, T. D., and von Bodman, S. B. 2006. Quorum-sensing regulation governs bacterial adhesion, biofilm development, and host colonization in Pantoea stewartii subspecies stewartii. Proc. Natl. Acad. Sci. U.S.A. 103:5983-5988.

Laue, H., Schenk, A., Li, H., Lambertsen, L., Neu, T. R., Molin, S., and Ullrich, M. S. 2006. Contribution of alginate and levan production to biofilm formation by Pseudomonas syringae. Microbiology 152:2909-2918.

Leid, J. G., Willson, C. J., Shirtliff, M. E., Hassett, D. J., Parsek, M. R., and Jeffers, A. K. 2005. The exopolysaccharide alginate protects Pseudomonas aeruginosa biofilm bacteria from IFN-gamma-mediated macrophage killing. J. Immunol. 175:7512-7518.

Li, Y., Tang, J., Tang, D., and Ma, Q. 2001. Pathogenicity of EPS-deficient mutants (gumB-, gumD and gumE-) of Xanthomonas campestris pv. campestris. Prog. Nat. Sci. 11:871-875.

Marco, M. L., Legac, J., and Lindow, S. E. 2005. Pseudomonas syringae genes induced during colonization of leaf surfaces. Environ. Microbiol. 7:1379-1391.

Morris, C. E., Monier, J. M., and Jacques, M. A. 1998. A technique to quantify the population size and composition of the biofilm component in communities of bacteria in the phyllosphere. Appl. Environ. Microbiol. 64:4789-4795.

Muller, P., Keller, M., Weng, W. M., Quandt, J., Arnold, W., and Puhler, A. 1993. Genetic analysis of the Rhizobium meliloti exoYFQ operon: ExoY is homologous to sugar transferases and ExoQ represents a transmembrane protein. Mol. Plant-Microbe Interact. 6:55-65.

Newman, M. A., Conrads-Strauch, J., Scofield, G., Daniels, M. J., and Dow, J. M. 1994. Defense-related gene induction in Brassica campestris in response to defined mutants of Xanthomonas campestris with altered pathogenicity. Mol. Plant-Microbe Interact. 7:553-563.

Osiro, D., Colnago, L. A., Otoboni, A. M., Lemos, E. G., de Souza, A. A., Coletta Filho, H. D., and Machado, M. A. 2004. A kinetic model for Xylella fastidiosa adhesion, biofilm formation, and virulence. FEMS (Fed. Eur. Microbiol. Soc.) Microbiol. Lett. 236:313-318.

Parsek, M. R., and Fuqua, C. 2004. Biofilms 2003: emerging themes and challenges in studies of surface-associated microbial life. J. Bacteriol. 186:4427-4440.

Parsek, M. R., and Singh, P. K. 2003. Bacterial biofilms: an emerging link to disease pathogenesis. Annu. Rev. Microbiol. 57:677-701.

Qian, W., Jia, Y., Ren, S. X., He, Y. Q., Feng, J. X., Lu, L. F., Sun, Q., Ying, G., Tang, D. J., Tang, H., Wu, W., Hao, P., Wang, L., Jiang, B. L., Zeng, S., Gu, W. Y., Lu, G., Rong, L., Tian, Y., Yao, Z., Fu, G., Chen, B., Fang, R., Qiang, B., Chen, Z., Zhao, G. P. Tang, J. L., and He, C. 2005. Comparative and functional genomic analyses of the pathogenicity of phytopathogen Xanthomonas campestris pv. campestris. Genome Res. 15:757-767.

Quinones, B., Pujol, C. J., and Lindow, S. E. 2004. Regulation of AHL production and its contribution to epiphytic fitness in Pseudomonas syringae. Mol. Plant-Microbe Interact. 17:521-531.

Quinones, B., Dulla, G., and Lindow, S. E. 2005. Quorum sensing regulates exopolysaccharide production, motility, and virulence in Pseudomonas syringae. Mol. Plant-Microbe Interact. 18:682-693.

Ramey, B. E., Koutsoudis, M., von Bodman, S. B., and Fuqua, C. 2004. Biofilm formation in plant-microbe associations. Curr. Opin. Microbiol. 7:602-609.

Russo, D. M., Williams, A., Edwards, A., Posadas, D. M., Finnie, C., Dankert, M., Downie, J. A., and Zorreguieta, A. 2006. Proteins exported via the PrsD-PrsE type I secretion system and the acidic exopolysaccharide are involved in biofilm formation by Rhizobium leguminosarum. J. Bacteriol. 188:4474-4486.

Ryan, R. P., Fouhy, Y., Lucey, J. F., Crossman, L. C., Spiro, S., He, Y. W., Zhang, L. H., Heeb, S., Camara, M., Williams, P., and Dow, J. M. 2006. Cell-cell signaling in Xanthomonas campestris involves an HD-GYP domain protein that functions in cyclic di-GMP turnover. Proc. Natl. Acad. Sci. U.S.A. 103:6712-6717.

Sambrook, J., Fritsch, E. F., and Maniatis, T. 1989. Molecular Cloning: A
Laboratory Manual, 2nd ed. Cold Spring Harbor Laboratory Press, Cold Spring Harbor, NY, U.S.A.

Schell, M. A. 2000. Control of virulence and pathogenicity genes of Ralstonia Solanacearum by an elaborate sensory network. Annu. Rev. Phytopathol. 38:263-292.

Sherwood, M. 1970. Improved synthetic medium for the growth of Rhizobium. J. Appl. Bacteriol. 33:708-713.

Siciliano, F., Torres, P., Sendin, L., Bermejo, C., Filippone, P., Vellice, G. Ramallo, J., Castagnaro, A., Vojnov, A., and Marano, M. R. 2006. Analysis of the molecular basis of Xanthomonas axonopodis pv. citri pathogenesis in Citrus limon. Electron. J. Biotechnol. 9:200-204.

Sivan, A., Szanto, M., and Pavlov, V. 2006. Biofilm development of the polyethylene-degrading bacterium Rhodococcus ruber. Appl. Microbiol. Biotechnol. 72:346-352.

Slater, H., Alvarez-Morales, A., Barber, C. E., Daniels, M. J., and Dow, J. M. 2000. A two-component system involving an HD-GYP domain protein links cell-cell signalling to pathogenicity gene expression in Xanthomonas campestris. Mol. Microbiol. 38:986-1003.

Solano, C., Garcia, B., Valle, J., Berasain, C., Ghigo, J. M., Gamazo, C., and Lasa, I. 2002. Genetic analysis of Salmonella enteritidis biofilm formation: critical role of cellulose. Mol. Microbiol. 43:793-808.

Southey-Pillig, C. J., Davies, D. G., and Sauer, K. 2005. Characterization of temporal protein production in Pseudomonas aeruginosa biofilms. J. Bacteriol. 187:8114-8126.

Souza, L. C., Wulff, N. A., Gaurivaud, P., Mariano, A. G., Virgilio, A. C., Azevedo, J. L., and Monteiro, P. B. 2006. Disruption of Xylella fastidiosa CVC gumB and gumF genes affects biofilm formation without a detectable influence on exopolysaccharide production. FEMS (Fed. Eur. Microbiol. Soc.) Microbiol. Lett. 257:236-242.

Steinberger, R. E., and Holden, P. A. 2005. Extracellular DNA in singleand multiple-species unsaturated biofilms. Appl. Environ. Microbiol. 71:5404-5410.

Stoodley, P., Sauer, K., Davies, D. G., and Costerton, J. W. 2002. Biofilms as complex differentiated communities. Annu. Rev. Microbiol. 56:187209.

Stuurman, N., Pacios Bras, C., Schlaman, H. R., Wijfjes, A. H., Bloemberg, G., and Spaink, H. P. 2000. Use of green fluorescent protein color variants expressed on stable broad-host-range vectors to visualize rhizobia interacting with plants. Mol. Plant-Microbe Interact. 13:1163-1169.

Sutherland, I. 2001. Biofilm exopolysaccharides: a strong and sticky framework. Microbiology 147:3-9.

Ude, S., Arnold, D. L., Moon, C. D., Timms-Wilson, T., and Spiers, A. J. 2006. Biofilm formation and cellulose expression among diverse environmental Pseudomonas isolates. Environ. Microbiol. 8:1997-2011.

Vojnov, A. A., Zorreguieta, A., Dow, J. M., Daniels, M. J., and Dankert, M. A. 1998. Evidence for a role for the gumB and gumC gene products in the formation of xanthan from its pentasaccharide repeating unit by Xanthomonas campestris. Microbiology 144:1487-1493.

Vojnov, A. A., Slater, H., Daniels, M. J., and Dow, J. M. 2001. Expression of the gum operon directing xanthan biosynthesis in Xanthomonas campestris and its regulation in planta. Mol. Plant-Microbe Interact. 14:768-774.

Vojnov, A. A., Bassi, D. E., Daniels, M. J., and Dankert, M. A. 2002. Biosynthesis of a substituted cellulose from a mutant strain of Xanthomonas campestris. Carbohydr. Res. 337:315-326.

Wozniak, D. J., Wyckoff, T. J., Starkey, M., Keyser, R., Azadi, P., O’Toole, G. A., and Parsek, M. R. 2003. Alginate is not a significant component of the extracellular polysaccharide matrix of PA14 and PAO1 Pseudomonas aeruginosa biofilms. Proc. Natl. Acad. Sci. U.S.A. 100:79077912.

Wu, H., Sparks, C., Amoah, B., and Jones, H. D. 2003. Factors influencing successful Agrobacterium-mediated genetic transformation of wheat. Plant Cell. Rep. 21:659-668.

Yun, M. H., Torres, P. S., El Oirdi, M., Rigano, L. A., Gonzalez-Lamothe, R., Marano, M. R., Castagnaro, A. P., Dankert, M. A., Bouarab, K., and Vojnov, A. A. 2006. Xanthan induces plant susceptibility by suppressing callose deposition. Plant Physiol. 141:178-187. 